\title{
The river Rhine: a global highway for dispersal of aquatic invasive species
}

\author{
Rob S. E. W. Leuven · Gerard van der Velde • \\ Iris Baijens $\cdot$ Janneke Snijders $\cdot$ Christien van der Zwart • \\ H. J. Rob Lenders · Abraham bij de Vaate
}

Received: 15 February 2008/ Accepted: 19 February 2009/Published online: 25 June 2009

(C) The Author(s) 2009. This article is published with open access at Springerlink.com

\begin{abstract}
The river Rhine is heavily influenced by human activities and suffers from a series of environmental constraints which hamper a complete recovery of biodiversity. These constraints comprise intensive navigation and habitat modification by hydraulic engineering. Improving water quality while these constraints remain in place has led to increased colonization by aquatic invasive species. This tendency has been accelerated by the construction of canals connecting river basins. Over the last two centuries, the total surface area of river catchments connected to the river Rhine via inland waterways has been increased by a factor 21.6. Six principal invasion corridors for aquatic species to the river Rhine are discerned. The extensive network of inland waterways has allowed macroinvertebrate species from different bio-geographical regions to mix,
\end{abstract}

R. S. E. W. Leuven $(\bowtie) \cdot$ I. Baijens · J. Snijders ·

C. van der Zwart . H. J. R. Lenders

Department of Environmental Science, Institute for

Wetland and Water Research (Partner institute of the

Netherlands Centre for River Studies), Radboud

University Nijmegen, P.O. Box 9010, 6500 GL Nijmegen,

The Netherlands

e-mail: r.leuven@science.ru.nl

G. van der Velde

Department of Animal Ecology and Ecophysiology,

Institute for Wetland and Water Research (Partner

institute of the Netherlands Centre for River Studies),

Radboud University Nijmegen, P.O. Box 9010, 6500 GL

Nijmegen, The Netherlands changing communities, affecting the food webs and forming new constraints on the recovery of the native biodiversity. From the eighteenth century onward, in the freshwater sections of the river Rhine, a total of 45 non-indigenous macroinvertebrate species have been recorded. The average number of invasions per decade shows a sharp increase from $<1$ to 13 species. Currently, the contribution of non-indigenous species to the total species richness of macroinvertebrates in the river Rhine is $11.3 \%$. The Delta Rhine and Upper Rhine exhibit higher numbers of non-indigenous species than other river sections, because the sea ports in the Delta Rhine and the Main-Danube canal function as invasion gateways. Important donor areas are the Ponto-Caspian area and North America (44.4 and $26.7 \%$ of the non-indigenous macroinvertebrate species, respectively). Transport via shipping and

G. van der Velde

National Natural History Museum Naturalis, P.O. Box 9517, 2300 RA Leiden, The Netherlands

A. bij de Vaate

Ministry of Transport and Public Works, Institute for Inland Water Management and Waste Water Treatment (Partner institute of the Netherlands Centre for River Studies), P.O. Box 17, 8200 AA Lelystad,

The Netherlands

Present Address:

A. bij de Vaate

Waterfauna Hydrobiologisch Adviesbureau, Oostrandpark 30, 8212 AP Lelystad, The Netherlands 
dispersal via man made waterways are the most important dispersal vectors. Intentional and unintentional introductions are highest for the period 19501992. The cumulative number of non-indigenous species in time is significantly correlated with the increase in total surface area of other river catchments connected to the river Rhine by means of networks of canals. The species richness of non-indigenous macroinvertebrates is strongly dominated by crustaceans and molluscs. Invasive species often tolerate higher salt content, temperature, organic pollution and current flow than native species. Spatiotemporal analyses of distribution patterns reveal that average and maximum dispersal rates of six invasive species vary between 44-112 and 137-461 km year ${ }^{-1}$, respectively. Species arriving in upstream sections first show a shorter time lag between colonisation of the Delta and Upper Rhine than species initially arriving in downstream areas. Temporal analyses of macroinvertebrate assemblages in the littoral zones indicate that native species are displaced by nonindigenous species. However, established non-indigenous species are also displaced by more recent mass invaders.

Keywords Dispersal rate - Invasion corridor . Macroinvertebrates - Non-indigenous species . Shipping - Species replacement · Waterways

\section{Introduction}

The river Rhine is the primary artery of one of the most important economic regions of Europe. The river has a total length of about $1,250 \mathrm{~km}$, a drainage area of circa $185,260 \mathrm{~km}^{2}$ and an average discharge of about 2,300 $\mathrm{m}^{3} \mathrm{~s}^{-1}$ (Uehlinger et al. 2009). Nine states are in part or entirely situated within its catchment (Austria, Belgium, France, Germany, Italy, Liechtenstein, Luxemburg, the Netherlands and Switzerland). Six morphologically and ecologically distinct river sections are distinguished (Van der Velde and Van den Brink 1994; IKSR 2002; Uehlinger et al. 2009): (1) the Alpine Rhine and its tributaries, i.e., the reach between the source (Lake Toma) and Lake Constance; (2) the High Rhine that flows from lower Lake Constance to Basel, there merging with the river Aare; (3) the Upper Rhine, flowing through the rift valley of the Rhine Graben that extends from Basel to Bingen with the rivers Neckar and Main as major tributaries; (4) the Middle Rhine, flowing through a narrow valley deeply incised in the Rhenish Slate Mountains and picking up waters of the river Mosel at Koblenz; (5) the Lower Rhine, extending from Bonn to Lobith with the rivers Ruhr, Emscher and Lippe as major tributaries; (6) the Delta Rhine in the Netherlands, where the river divides into three major distributaries called the Waal, Nederrijn, and IJssel (Fig. 1). The river provides services for transportation, power generation, industrial production, urban sanitation, drinking water, agriculture and tourism, and is a classic example of a multipurpose waterway (Van der Velde and Van den Brink 1994; Cioc 2002; Uehlinger et al. 2009). However, its biodiversity and ecological integrity are severely affected by these human activities (Van den Brink et al. 1990; Nienhuis et al. 2002; Bij de Vaate et al. 2006; Leuven et al. 2006; Nienhuis 2008; Uehlinger et al. 2009).

In spite of ambitious and successful rehabilitation programmes aiming at improvement of water quality, restoration of riverine ecosystems and enhancement of habitat connectivity, the river still suffers from a series of environmental constraints which hamper a complete recovery of biodiversity (Leuven and Poudevigne 2002; Nienhuis et al. 2002; Bij de Vaate et al. 2006; Van der Velde et al. 2006a, b; Van der Velde and Bij de Vaate 2008). Examples of these constraints are intensive navigation and irreversible habitat modification by hydraulic engineering (e.g., canalisation and construction of groynes and stony banks). Improving water quality while these constraints remain in place has led to increased colonization of the river Rhine by non-indigenous species that spread their geographic distribution and caused significant changes in composition, structure and ecosystem processes (Den Hartog et al. 1992; Bij de Vaate et al. 2002; Haas et al. 2002; Van der Velde et al. 2006a, b; Bernauer and Jansen 2006; Baur and Schmidlin 2007; Van Riel et al. 2006b; Panov et al. 2009).

The introduction of non-indigenous species in the river Rhine has occurred both intentionally and unintentionally (Van der Velde et al. 2002). In the past, several species have been introduced for aquaculture, fisheries or ornamental purposes. Examples of unintentional introductions are the release of 
Fig. 1 Geographical location of various river sections in the Rhine basin (a) and the river distributaries in the Delta Rhine (b)

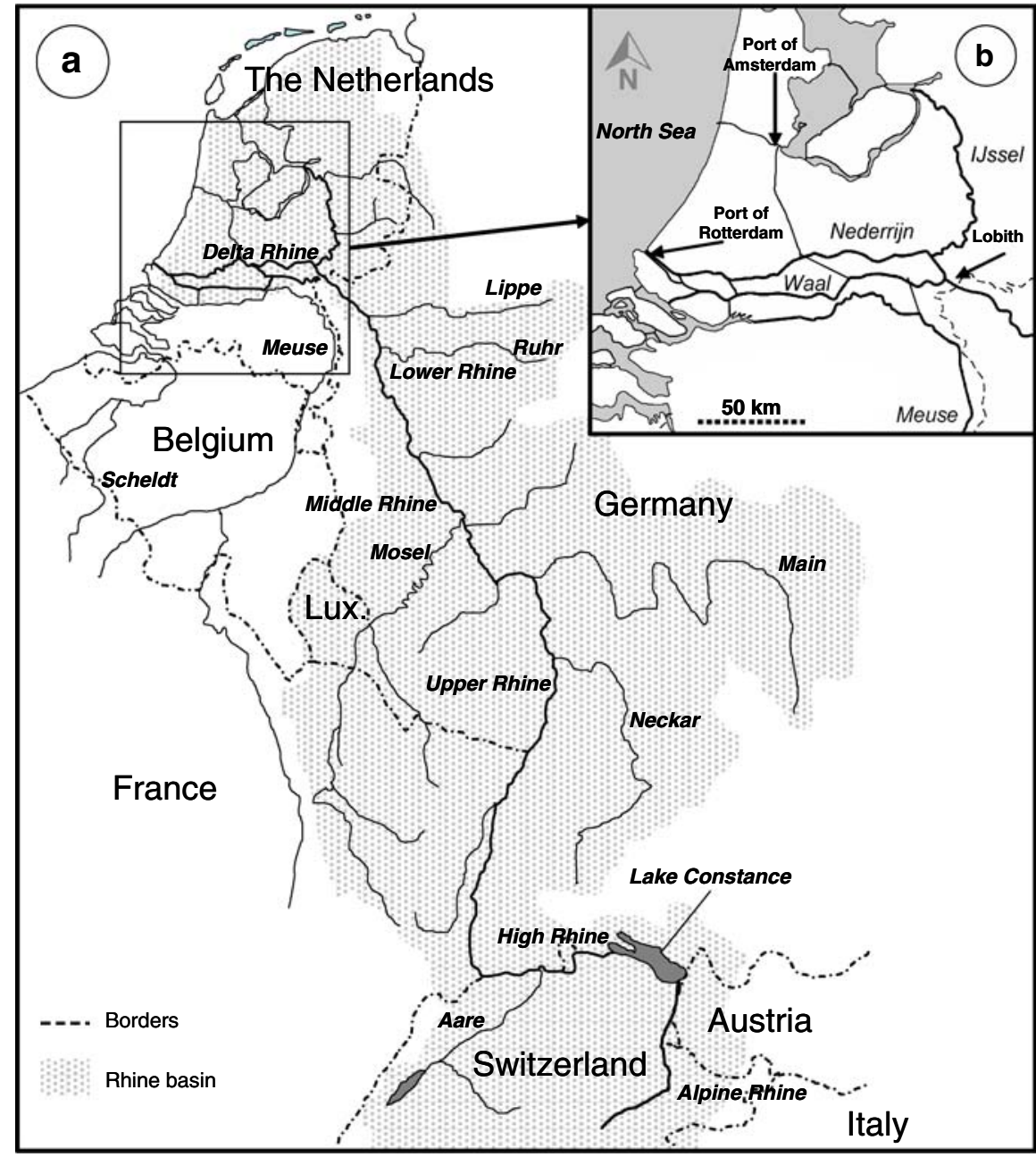

species via ballast water or via transport on ship hulls (Ricciardi and MacIsaac 2000). The ports in the Rhine delta are important gateways for non-indigenous species (Bij de Vaate et al. 2002). Moreover, the wish to expand navigation routes across river basin boundaries has led to the construction of navigation canals that connect the river Rhine with previously isolated catchments of the Caspian Sea, the southern European seas (Azov, Black and Mediterranean Sea), the northern European seas (Baltic, North and White Sea) and the Atlantic ocean (Galil et al. 2007; Panov et al. 2009). This network of waterways opened long distance dispersal routes for aquatic species from several bio-geographic areas (Bij de Vaate et al. 2002; Van der Velde et al. 2002; Arbačiauskas et al. 2008; Karatayev et al. 2008; Panov et al. 2009).
This paper describes the development of invasion corridors and the distribution of non-indigenous macroinvertebrate species in freshwater sections of the river Rhine. The study is restricted to aquatic macroinvertebrates that live in the main channel or connected bodies of water in its floodplains. The analysis of invasion pathways, vectors, dispersal rates, taxonomic richness and abundances in local communities is undertaken. The following research questions are addressed:

1. Which spatiotemporal developments in the European inland waterways and sea shipping routes lifted barriers for dispersal of non-indigenous species to the river Rhine?

2. Which non-indigenous species have established in various sections of the river and what are 
temporal patterns in their arrival, donor areas, pathways and dispersal vectors?

3. What are the long distance dispersal rates of nonindigenous species in the river Rhine and connected inland waterways?

4. Which trends in richness and abundance of nonindigenous species can be discerned in macroinvertebrate communities in littoral zones of the river Rhine?

Biological and environmental factors explaining dispersal and establishment of non-indigenous species in the river Rhine will be discussed.

\section{Materials and methods}

Analyses of the network of inland waterways and shipping activities

Data on spatiotemporal developments of the Eurasian network of inland waterways and sea shipping routes connected to the river Rhine were derived from scientific literature and internet sources (Table 1). Data on shipping activity, yearly discharge of ballast water and introduction rate of invasive species in the Port of Rotterdam were obtained from the Maritime and Coastguard Agency (2006).

Construction of database on non-indigenous species

Existing databases on the distribution of non-indigenous species in the Delta Rhine (Den Hartog and Van der Velde 1987; Van den Brink et al. 1990) were updated and extended with data on other river sections, using a distribution atlas on freshwater molluscs (Gittenberger et al. 1998), recent field surveys (Kelleher et al. 1998; Rajagopal et al. 2000; IKSR 2002; Bij de Vaate 2003; Bernauer and Jansen 2006; Bij de Vaate et al. 2006, 2007), monitoring programmes of the Dutch Institute for Inland Water Management and Waste Water Treatment (RIZA), the database of the Dutch Working Group on Ecological Water Management, the Dutch Species Catalogue and several literature reviews (Bij de Vaate et al. 2002; Van der Velde et al. 2002; Gollasch and Nehring 2006; Van der Velde and Bij de Vaate 2008 and references therein). The following data attributes of non-indigenous species were collected: taxonomic group, species name, donor area, dispersal vector, pathway (invasion corridor), year and river section of initial arrival, and references. Data on initial record, origin, pathways and dispersal vectors of non-indigenous species were derived from scientific literature. Dispersal vectors were divided in six categories: (1) accidental release from aquaculture, escapes from garden ponds or dumping of aquaria or pond contents, (2) migration or drift via man made waterways (canals connecting rivers), (3) deliberate introduction by humans (e.g., for aquaculture, fisheries, weed control and pest management), (4) transported via seagoing ships (e.g., release from ballast water and ship hull fouling), (5) multiple vectors, and (6) vectors unknown.

Data on total species richness in various freshwater section of the river Rhine was derived from IKSR (2002). The abundances of native and non-indigenous species in macroinvertebrate assemblages on artificial substrates (baskets filled with marbles) in the littoral zone of the river Rhine near Lobith (rkm 882; Latitude $51^{\circ} 07^{\prime} 97^{\prime \prime}$, Longitude $05^{\circ} 55^{\prime} 26^{\prime \prime}$; see Fig. 1) were obtained from RIZA. Maximum densities of gammaridean species in the littoral zones of the Rhine river distributaries Waal, Nederrijn and IJssel (Fig. 1b) were obtained from monitoring programmes of RIZA and several field surveys (Van den Brink et al. 1991; Van der Velde et al. 2000, 2002; Van Riel 2007; Van Riel et al. 2009). During these field surveys specimens were cautiously brushed from artificial substrate (marbles), riprap and groyne stones, and subsequently preserved in $70 \%$ ethanol, sorted by species and counted in the laboratory. The total surface area of the marbles and stones was calculated in order to quantify the densities of macroinvertebrate species per square metre of substratum. The annual taxa richness and relative abundance of macroinvertebrates were based on pooled data (two baskets per sampling date; four to seven sampling dates per year; sampling from spring to autumn).

Assessment of richness and abundance of non-indigenous species

Trends in richness and abundance of non-indigenous species in the macroinvertebrate communities of the littoral zones of the river Rhine were analysed using the Taxonomic Contamination Index (TCI), the Abundance Contamination Index (ACI) and the Site- 
Table 1 Connections of European rivers via canals (Fig. 2 visualises the European network of inland waterways)

\begin{tabular}{|c|c|c|c|c|}
\hline \multirow{2}{*}{$\frac{\text { Canal }}{\text { Elbe-Lübeck Canal }^{\mathrm{i}}}$} & \multicolumn{2}{|c|}{ Connection between rivers/seas } & \multirow{2}{*}{$\frac{\text { Year of opening }}{1398}$} & \multirow{2}{*}{$\frac{\text { References }}{\text { www.en.wikipedia.org }}$} \\
\hline & Elbe & Baltic Sea & & \\
\hline Havel-Oder Canal & Elbe & Oder & $1640^{\mathrm{a}}$ & Galil et al. (2007) \\
\hline Canal de Briare & Seine & Loire & $1642^{\mathrm{b}}$ & www.beluga-on-tour.de \\
\hline Friedrich-Wilhelm Canal ${ }^{\mathrm{j}}$ & Elbe & Oder & $1668^{c}$ & www.de.wikipedia.org \\
\hline Mariinsk Canal System & Volga & Baltic Sea & $1709^{\mathrm{d}}$ & www.en.wikipedia.org \\
\hline Bydgoszcz Canal & Oder & Vistula & 1774 & www.britannica.com \\
\hline Oginsky Canal & Dnieper & Neman & $1784^{\mathrm{e}}$ & Karatayev et al. (2008) \\
\hline Canal de Centre & Loire & Rhône & 1792 & Galil et al. (2007) \\
\hline Canal de Bourgogne & Seine & Rhône & 1832 & www.en.wikipedia.org \\
\hline Charleroi-Brussels Canal & Meuse & Scheldt & 1832 & www.en.wikipedia.org \\
\hline Rhône-Rhine Canal & Rhine & Rhône & 1834 & Galil et al. (2007) \\
\hline Ludwig Canal & Rhine & Danube & $1846^{\mathrm{f}}$ & Galil et al. (2007) \\
\hline Dnieper-Bug Canal ${ }^{\mathrm{k}}$ & Dnieper & Vistula & 1848 & Karatayev et al. (2008) \\
\hline Rhine-Marne Canal & Rhine & Seine & 1853 & Galil et al. (2007) \\
\hline Canal de la Meuse $^{1}$ & Meuse & Rhine/Seine & 1884 & www.de.wikipedia.org \\
\hline Hunte-Ems Canal & Ems & Weser & 1893 & www.de.wikipedia.org \\
\hline Dortmund-Ems Canal & Rhine & Ems & 1899 & Galil et al. (2007) \\
\hline Rhine-Herne Canal & Rhine & Ems & 1914 & Galil et al. (2007) \\
\hline Meuse-Waal Canal & Rhine & Meuse & 1927 & www.nl.wikipedia.org \\
\hline White Sea-Baltic Sea Canal & White Sea & Baltic Sea & 1932 & Galil et al. (2007) \\
\hline Mittelland Canal & Weser & Elbe & $1938^{\mathrm{g}}$ & Galil et al. (2007) \\
\hline Augustow Canal & Vistula & Neman & 1938 & www.it.mazury.pl \\
\hline Volga-Don Canal & Volga & Don & 1952 & Galil et al. (2007) \\
\hline Scheldt-Rhine Canal & Rhine & Scheldt & $1975^{\mathrm{h}}$ & www.rijkswaterstaat.nl \\
\hline Main-Danube Canal & Rhine & Danube & 1992 & Galil et al. (2007) \\
\hline
\end{tabular}

a In 1746 re-opened after major constructions

b Galil et al. (2007) give 1842

c Earlier link between Elbe and Oder via Havel-Oder Canal

d Date of first connection, Galil et al. (2007) give 1810/1964 as dates of completion of this canal system

e Probably closed in 1915

${ }^{\mathrm{f}}$ Closed in 1950

g This canal connects the rivers Ems and Elbe through the Weser; in 1893 the rivers Ems and Weser were also connected by means of the Hunte-Ems Canal

h After 1986 free of tidal influence

${ }^{\mathrm{i}}$ Elbe-Trave Canal or Stecknitz Canal

j Müllroser Canal

k Krolevski Canal

${ }^{1}$ Links up with Rhine-Marne Canal

specific Biological Contamination Index (SBCI) (Arbačiauskas et al. 2008; Panov et al. 2009). TCI $=R_{\text {nis }} / R_{\mathrm{t}}$ : where $R_{\text {nis }}$ is the total number of non-indigenous species, while $R_{\mathrm{t}}$ is the total number of identified species. ACI is the relative abundance of non-indigenous species in a sample. With ACI and
TCI scores, the SBCI was derived from the reference table of Arbačiauskas et al. (2008) for the classification of sampling sites corresponding to ecological quality classes of the European Union Water Framework Directive (European Community 2000). SBCI ranks from 0 to 4 (0: no biocontamination, "high" 
ecological status; 1: low biocontamination, "good" ecological status; 2: moderate biocontamination, "moderate" ecological status; 3: high biocontamination, "poor" ecological status; 4: very high biocontamination, "bad" ecological status).

\section{Dispersal rates}

Long-distance dispersal rates of non-indigenous species were estimated using literature records on the spatiotemporal distribution of aquatic invaders in the river Rhine and connected waterways. Due to lack of detailed observations on species distribution patterns and data on exact time of initial arrival, dispersal rates of non-indigenous species were calculated conservatively using year of first recorded sighting and shortest migration route via the network of inland waterways. Data on geographical locations was always transformed to river or canal kilometres for calculations of singular dispersal distance. Dispersal rates could not be corrected for possible lags of time between dates of initial arrival and first observation.

\section{Statistics}

Statistical significance of regression models for the cumulative numbers of non-indigenous species versus the years of arrival and catchment area connected to the river Rhine was analysed using ANOVA. A paired two-sample $t$-test, assuming unequal variances, was performed to determine whether dispersal rates significantly differ for various species. Data on dispersal rate was log-transformed prior to statistical testing. Data was considered statistically significant at $P<0.05$. All statistical analyses were performed with SPSS 15.0.

\section{Results}

Building of water networks resulting in invasion corridors

The wish to expand navigation routes across river basin boundaries has led to the construction of an extensive network of navigation canals that connect the river Rhine with nearly all large rivers in southwestern, southern, central and eastern Europe, and beyond (Fig. 2). Table 1 summarizes the years of opening of the connections between rivers associated with relevant references. Important steps for the connection of the river Rhine to the Eurasian network of inland waterways were: (1) the connection of the river Scheldt with the rivers Meuse and Rhine after opening of the Charleroi-Brussels Canal in 1832; (2)
Fig. 2 Connections between the river Rhine and large rivers in Europe via canals and sea routes (Light grey boxes: large rivers; dark grey boxes: receiving seas; continuous lines: natural discharge; dotted lines: main artificial canal systems including dates of completion/opening up of canals)

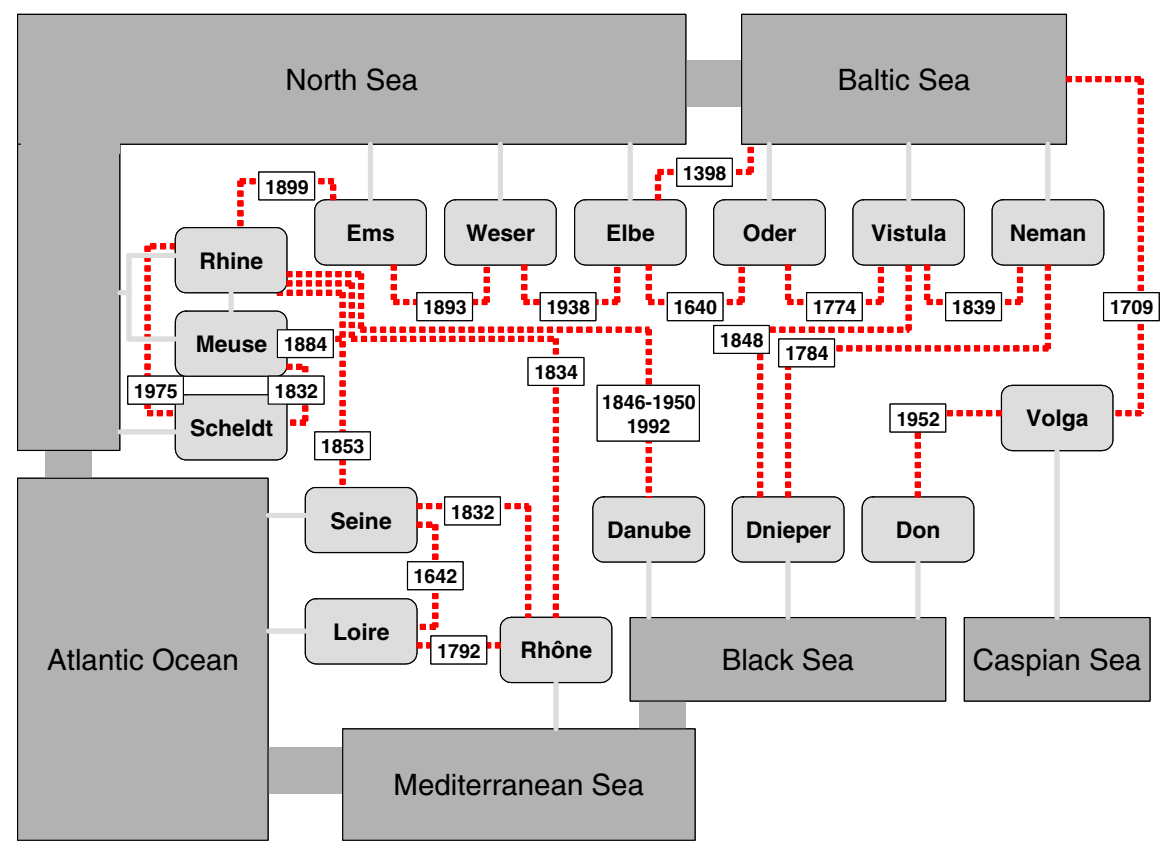




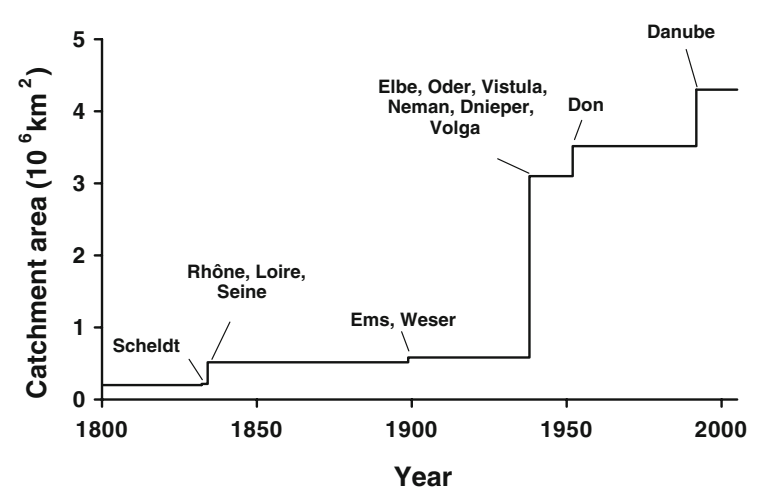

Fig. 3 Punctuated increase in surface area of river catchments connected to the river Rhine due to constructions of canals (Table 1)

the connection of the rivers Rhône, Loire and Seine via the Rhône-Rhine Canal in 1834; (3) the connection of the rivers Ems and Weser after construction of the Dortmund-Ems Canal; (4) the connection with the central and eastern European rivers Elbe, Oder, Vistula, Neman, Dnieper and Volga after the opening of the Mittelland Canal between the rivers Weser and Elbe in 1938; (5) the connection with the river Don in 1952 after construction of the Volga-Don Canal; (6) the connection with the river Danube after the reopening of the Main-Danube Canal in 1992. At present, the network of inland waterways is made up of circa $28,000 \mathrm{~km}$ of navigable rivers and canals, connecting 37 countries in Europe and beyond. Figure 3 visualises the spatiotemporal expansion of this network of waterways. The total surface area of river catchments connected to the river Rhine via canals shows a stepwise increase from $0.19 \times 10^{6}$ to $4.30 \times 10^{6} \mathrm{~km}^{2}$ since the eighteenth century (i.e., an increase with a factor 21.6).

The Eurasian network of inland waterways and sea shipping routes offers nowadays six invasion corridors for aquatic species to the river Rhine (Fig. 4): (1) The Northern corridor, connecting the catchments of the Black, Azov and Caspian seas via the VolgaDon Canal, and the Baltic and White seas via the Volga-Baltic Canal and White Sea-Baltic Sea Canal and the river Rhine via sea shipping; (2) The Central corridor, connecting the Black Sea basin with the Baltic Sea region via the Dnieper and Bug-Pripyat Canal and with the North Sea basin via an extensive network of waterways; (3) The Southern corridor, linking the Black Sea basin with the North Sea basin via the Danube-Main-Rhine waterway; (4) The South-western corridor, linking the rivers Loire and Seine; (5) The Mediterranean corridor, linking the Mediterranean basin with the North Sea basin via the Rhône and the Rhine-Rhône Canal; (6) The transatlantic and North Sea shipping routes to various sea harbours in the Rhine delta. The sea shipping routes (including the Northern corridor) had already been effective as pathways for dispersal of non-indigenous species to the river Rhine for many centuries. However, in the twentieth century their importance for species dispersal strongly increased due to the expansion of global trade and improvements in shipping technology (e.g., the introduction of ballast water tanks). The South-western and Mediterranean corridors were connected to the river Rhine in 1834 . The Central and Southern corridors were completed in 1938 and 1992, respectively.

The Port of Rotterdam is the terminus of Rhine navigation and Europe's largest seaport with circa 30,000 sea going ships and 130,000 inland ships arriving per year. According to the Maritime and Coastguard Agency (2006) the yearly discharge of ballast water is estimated to be 5 billion tons. Most ballast water originates from North Sea (50\%), Baltic (11\%) and European Atlantic (11\%) routes. Of the remaining $28 \%$, most ships originated from the Mediterranean, American, tropical and fresh water routes, although information on shipping routes of ships is often incomplete. The introduction rate of non-indigenous species via ballast water import is estimated to be 1 species every 4 years (Maritime and Coastguard Agency 2006). However, most of these species can only survive in marine and estuarine environments and are not able to establish viable populations in the freshwater sections of the river Rhine.

In the freshwater sections of the river Rhine a total of 45 non-indigenous invertebrate species were recorded from the eighteenth century onward (Table 2). The number of non-indigenous species recorded was highest in the Delta Rhine and Upper Rhine (42 and 37 species, respectively: Fig. 5). The High Rhine exhibited the lowest number of nonindigenous species; the Lower and Middle Rhine held an intermediate position. The contribution of nonindigenous species to total species richness of macroinvertebrates in the Rhine was $11.3 \%$. Relative contribution was highest in the Delta Rhine (48.8\%) 


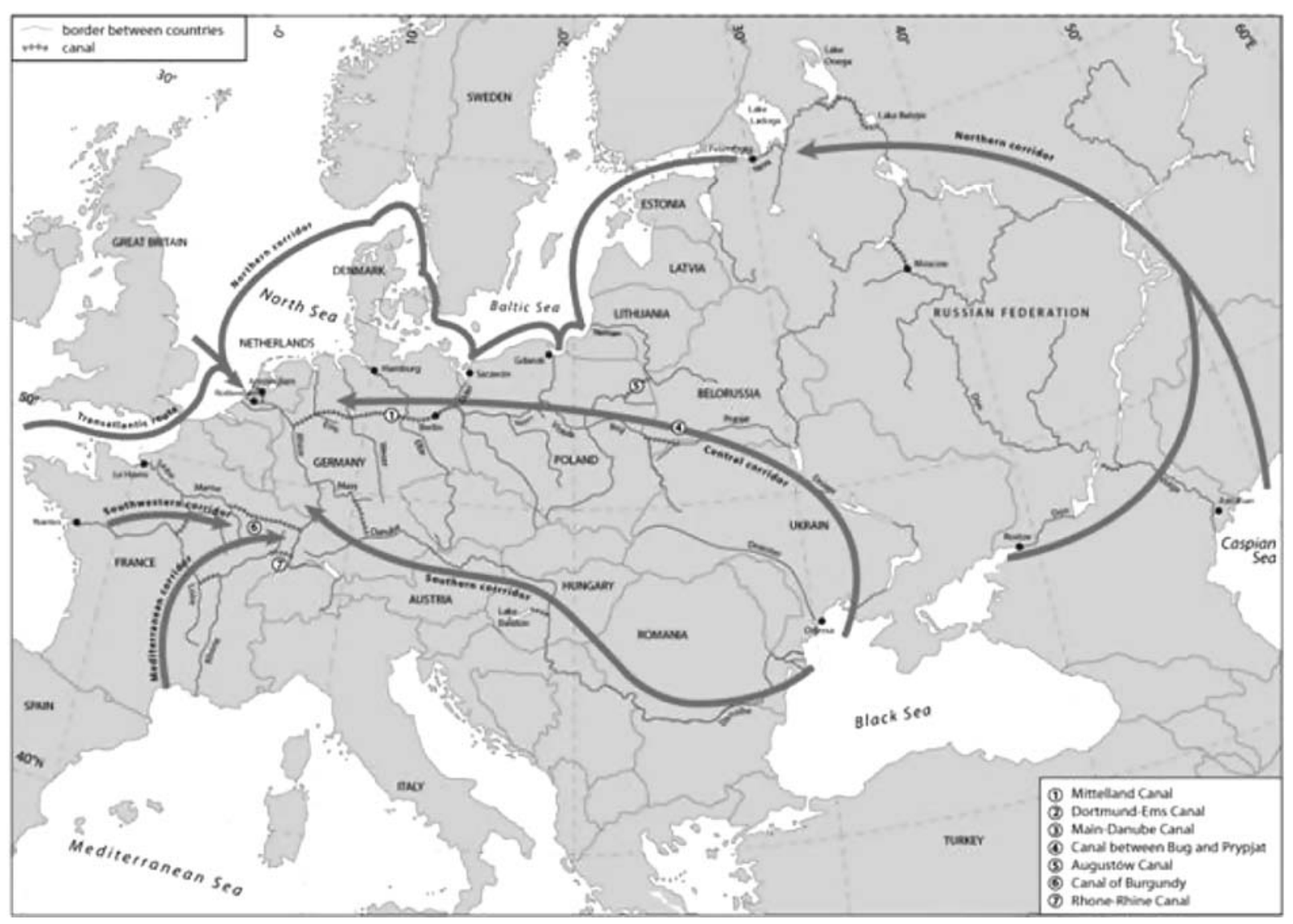

Fig. 4 Principal dispersal corridors for aquatic invasive species to the river Rhine, modified from Bij de Vaate et al. (2002) and Panov et al. (2009)

and lowest in the High Rhine (11.2\%). No records of non-indigenous species were available for the Alpine Rhine and its tributaries.

Taxonomic composition of the non-indigenous macroinvertebrate fauna and their origin

Of the non-indigenous macroinvertebrate species, crustacean species were most numerous (51.1\%), including nine amphipod, eight decapod, three isopod, two mysid and one cladoceran species (Table 3). Mollusc species contributed to $22.2 \%$ of the total number of non-indigenous species. These molluscs were represented by five species of snails and five species of bivalves. Annelid and triclad species contributed to 11.1 and $4.4 \%$ of the non-indigenous species, respectively. The occurrence of the remaining taxonomic groups was low $(2.2 \%$ for mite, bryozoan, hydrozoan, leech and caddis larva species).
Taxonomic contamination (TCI) differed remarkably for various invertebrate groups (1.7-76.7\%; in total $23.1 \%$ for all discerned taxa). Most non-indigenous species originated from the Ponto-Caspian area and from North America (44.4 and 26.7\% of the total number of non-indigenous species, respectively). Southern Europe, Asia, Northern Europe and Oceania contributed to $13.3,11.1,2.2$ and $2.2 \%$ of the nonindigenous species, respectively (in total 28.8\%).

Increasing numbers of non-indigenous species

The introductions and invasions of non-indigenous species in the river Rhine strongly increased over the period 1800-2005 (Fig. 6). The cumulative number of non-indigenous species in time shows a punctuated pattern, but the data significantly fit a power function (ANOVA: $P<0.001$ ). The average number of records of new non-indigenous species per time period 


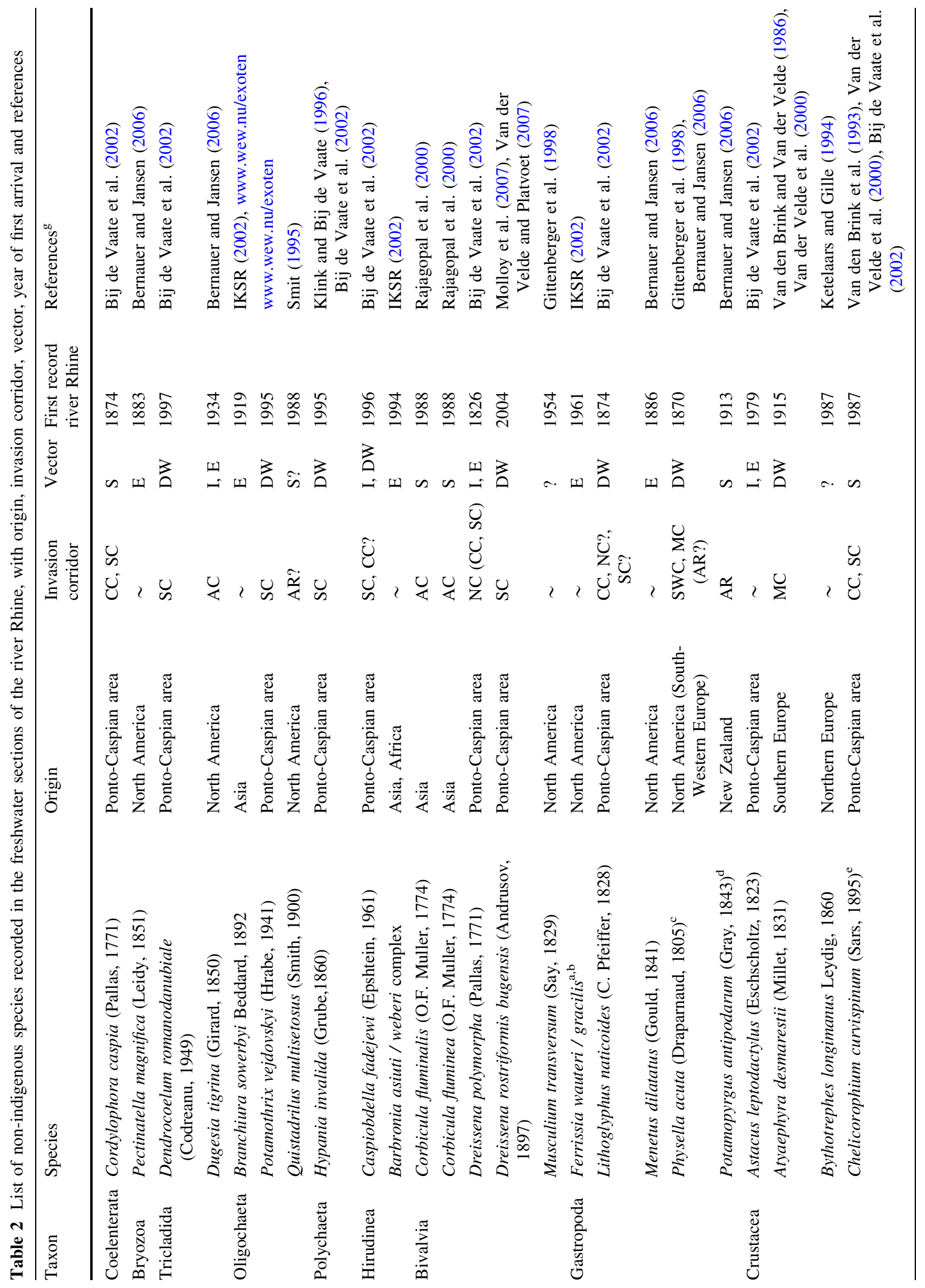




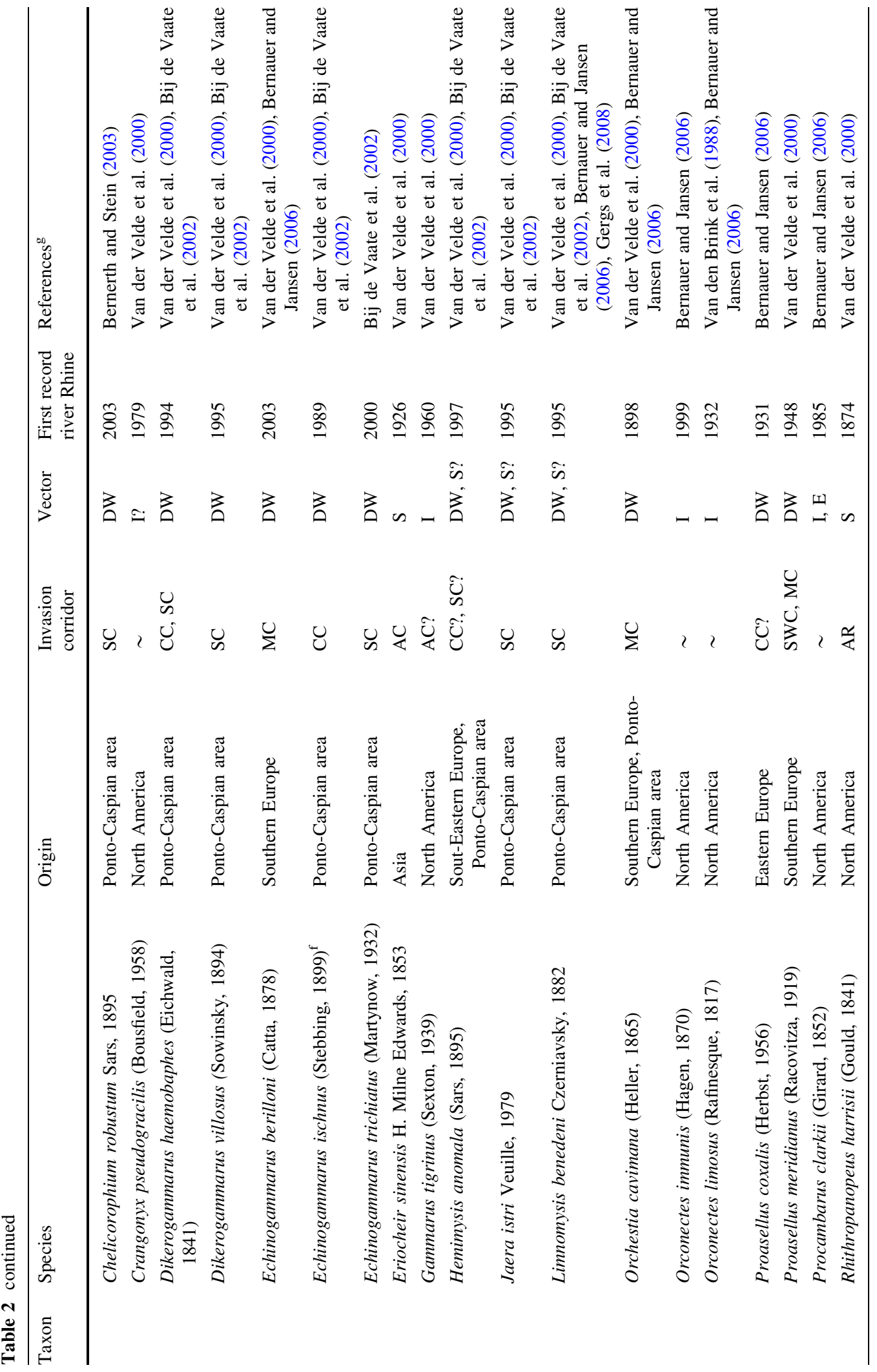



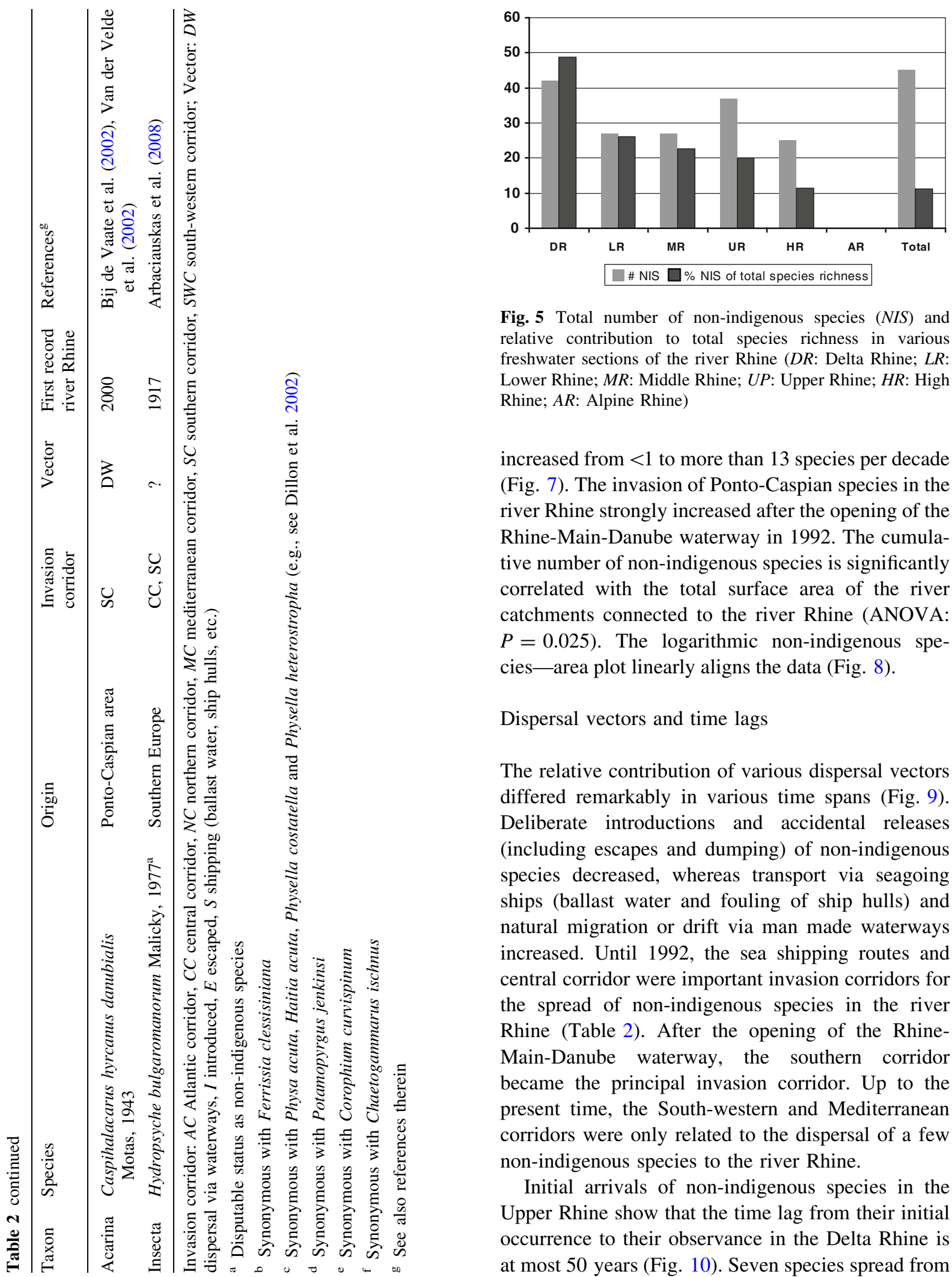

Fig. 5 Total number of non-indigenous species (NIS) and relative contribution to total species richness in various freshwater sections of the river Rhine (DR: Delta Rhine; $L R$ : Lower Rhine; $M R$ : Middle Rhine; UP: Upper Rhine; HR: High Rhine; AR: Alpine Rhine)

increased from $<1$ to more than 13 species per decade (Fig. 7). The invasion of Ponto-Caspian species in the river Rhine strongly increased after the opening of the Rhine-Main-Danube waterway in 1992. The cumulative number of non-indigenous species is significantly correlated with the total surface area of the river catchments connected to the river Rhine (ANOVA: $P=0.025)$. The logarithmic non-indigenous species - area plot linearly aligns the data (Fig. 8).

Dispersal vectors and time lags

The relative contribution of various dispersal vectors differed remarkably in various time spans (Fig. 9). Deliberate introductions and accidental releases (including escapes and dumping) of non-indigenous species decreased, whereas transport via seagoing ships (ballast water and fouling of ship hulls) and natural migration or drift via man made waterways increased. Until 1992, the sea shipping routes and central corridor were important invasion corridors for the spread of non-indigenous species in the river Rhine (Table 2). After the opening of the RhineMain-Danube waterway, the southern corridor became the principal invasion corridor. Up to the present time, the South-western and Mediterranean corridors were only related to the dispersal of a few non-indigenous species to the river Rhine.

Initial arrivals of non-indigenous species in the Upper Rhine show that the time lag from their initial occurrence to their observance in the Delta Rhine is at most 50 years (Fig. 10). Seven species spread from 
Table 3 Contribution of non-indigenous species (NIS) to taxa richness of macroinvertebrates in the freshwater sections of the river Rhine

\begin{tabular}{lcccc}
\hline Taxon & $\begin{array}{l}\text { Total number of species } \\
\text { in 2000 (IKSR 2002) }\end{array}$ & $\begin{array}{l}\text { Number of NIS } \\
\text { in 2005 }\end{array}$ & $\begin{array}{l}\text { Percent NIS per taxon } \\
\text { of total number of NIS }\end{array}$ & $\begin{array}{l}\text { Percent NIS of total } \\
\text { number of species per taxon }\end{array}$ \\
\hline Acarina & 6 & 1 & 2.2 & 16.7 \\
Bryozoa & 6 & 1 & 2.2 & 16.7 \\
Hydrozoa & 2 & 1 & 2.2 & 50.0 \\
Hirudinea & 14 & 1 & 2.2 & 7.1 \\
Trichoptera & 58 & 1 & 2.2 & 1.7 \\
Tricladida & 6 & 2 & 4.4 & 33.3 \\
Annelida & 28 & 5 & 11.1 & 17.9 \\
Mollusca & 45 & 10 & 22.2 & 22.2 \\
Crustacea & 30 & 23 & 51.1 & 76.7 \\
Total & 195 & 45 & 100 & 23.1 \\
\hline
\end{tabular}

${ }^{\text {a }}$ Updated with data of Table 2

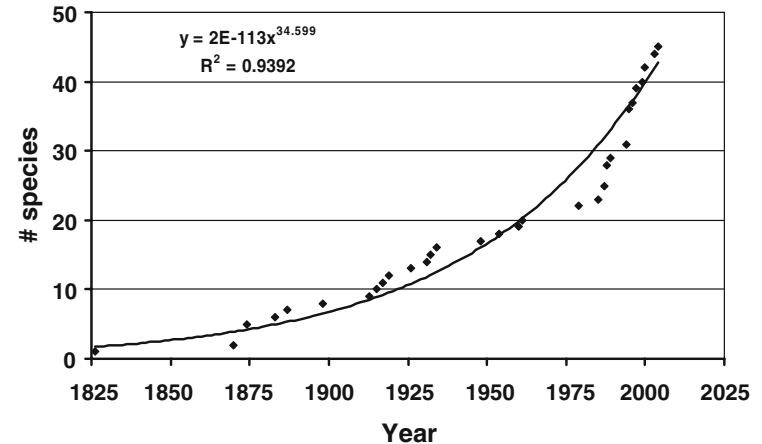

Fig. 6 Cumulative number of non-indigenous species in the freshwater sections of the river Rhine

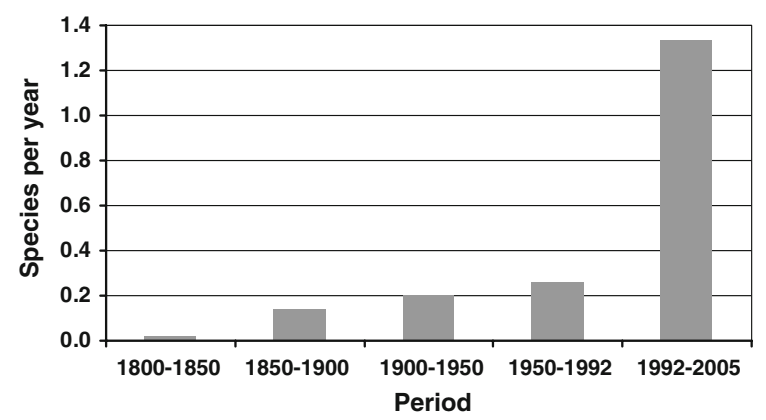

Fig. 7 Yearly average number of new non-indigenous species colonizing the freshwater sections of the river Rhine

the Upper Rhine to the Delta Rhine within 1 year. Upstream dispersal of species showed higher average and maximum time lags.

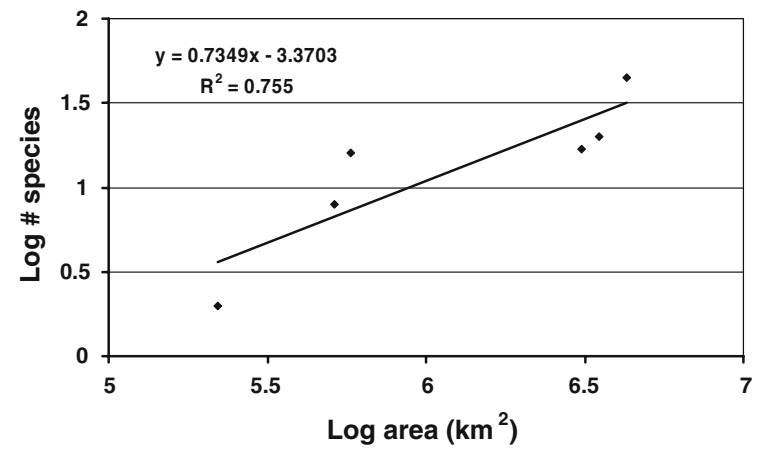

Fig. 8 Relation between the total number of non-indigenous species and the cumulative surface area of river catchments connected to the river Rhine

More detailed records on dispersal of six nonindigenous species in the river Rhine and connected waterways showed average dispersal rates of 44 $112 \mathrm{~km} \mathrm{year}^{-1}$ (Table 4). The minimum and maximum dispersal rates of species ranged between 14-58 and $137-461 \mathrm{~km}$ year ${ }^{-1}$, respectively. However, the mean log-transformed dispersal rates did not significantly differ (paired two-sample $t$-test; $P>0.05$ ).

Contribution of non-indigenous species in macroinvertebrate assemblages

Available data on macroinvertebrate assemblages in the littoral zone of the river Rhine at Lobith allowed the analyses of temporal trends in biocontamination with non-indigenous species over time (Fig. 11). In 


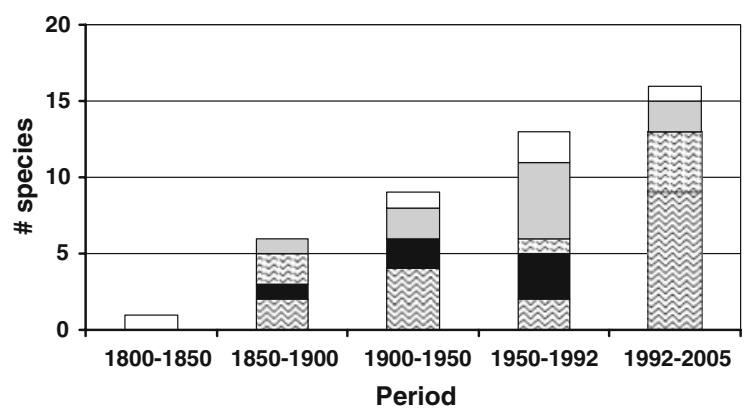

Waterways $\square$ Shipping图 Waterways / shipping $\square$ Introduced / escaped $\square$ Multiple

Fig. 9 Dispersal vectors of non-indigenous species in the Rhine river distributaries. Waterways: migration or drift via man made waterways (canals connecting river basins); Shipping: transported via seagoing ships (e.g., release from ballast water and ship hull fouling); Introduced/escaped: deliberate introduction by humans (e.g., for aquaculture, fisheries, weed control and pest management) or accidental release from aquaculture, escapes from garden ponds or dumping of aquaria or pond contents

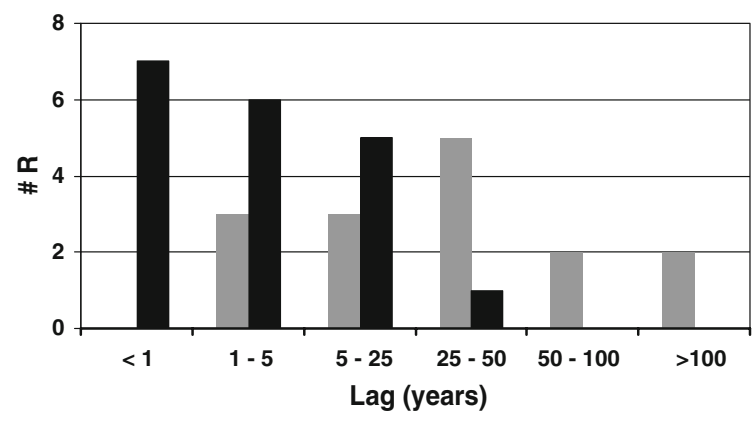

Delta Rhine -> Upper Rhine $\square$ Upper Rhine ->Delta Rhine

Fig. 10 Lag in first records of non-indigenous species in the Delta Rhine and Upper Rhine

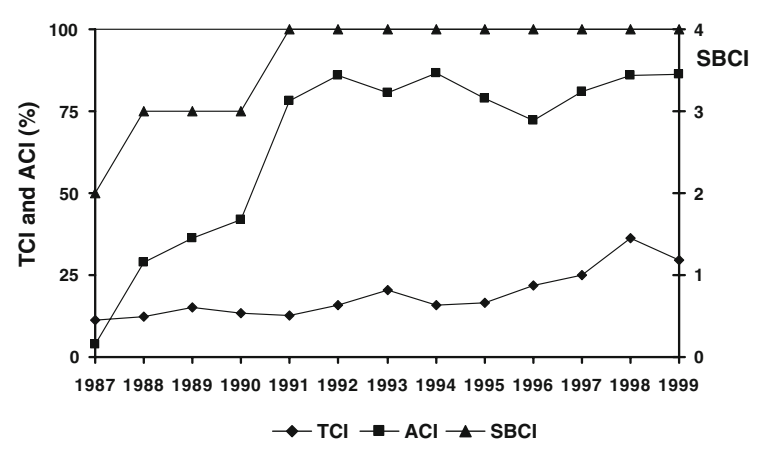

Fig. 11 Temporal changes of abundance contamination index $(A C I)$, taxonomic contamination index $(T C I)$ and site-specific biological contamination index $(S B C I)$ of the river Rhine near Lobith

total, 17 non-indigenous macroinvertebrate species were recorded from 1987 to 1999 in the local macroinvertebrate assemblages on artificial substrates. The taxonomic contamination at species level (TCI) increased from 11.1 to $36.1 \%$ over the period 1987-1998 and slightly decreased to $29.5 \%$ in 1999 . The increase in taxonomic contamination over this time span could be mainly attributed to invasions of Ponto-Caspian species after the opening of the RhineMain-Danube waterway in 1992. The abundance contamination steeply increased from 4 to $86.0 \%$ over the period 1987-1992, followed by a state of dynamic equilibrium with an average value of $82.2 \%$ over the period 1992-1999. High abundance contamination could be mainly attributed to seven invasive species, i.e., the isopod Jaera istri, the amphipods Chelicorophium curvispinum, Dikerogammarus villosus, Echinogammarus ischnus and Gammarus tigrinus, and the bivalve molluscs

Table 4 Dispersal rates of aquatic invasive species in European waterways $\left(\mathrm{km}\right.$ year $\left.{ }^{-1}\right)$

\begin{tabular}{|c|c|c|c|c|c|}
\hline Taxon/species & $\begin{array}{l}\text { Number } \\
\text { of records }\end{array}$ & $\begin{array}{l}\text { Mean } \\
\text { dispersal rate }\end{array}$ & $\begin{array}{l}\text { Standard } \\
\text { deviation }\end{array}$ & $\begin{array}{l}\text { Minimum } \\
\text { dispersal rate }\end{array}$ & $\begin{array}{l}\text { Maximum } \\
\text { dispersal rate }\end{array}$ \\
\hline \multicolumn{6}{|l|}{ Bivalvia } \\
\hline Corbicula fluminea & 6 & 63 & 95 & 27 & 276 \\
\hline Dreissena polymorpha & 3 & 65 & 93 & 14 & 199 \\
\hline \multicolumn{6}{|l|}{ Crustacea } \\
\hline Chelicorophium curvispinum & 6 & 44 & 46 & 14 & 137 \\
\hline Dikerogammarus villosus & 4 & 112 & 194 & 40 & 461 \\
\hline Jaera istri & 5 & 109 & 68 & 31 & 185 \\
\hline Obesogammarus obesus & 3 & 130 & 203 & 58 & 424 \\
\hline
\end{tabular}


Dreissena polymorpha and Corbicula fluminea. However, the relative contribution of each species changed remarkably during the sampling period (see also below). The ecological quality of the macroinvertebrate assemblages, as indicated by the site specific biocontamination index (SBCI), decreased from moderate (score 2) to bad (score 4), due to the high species richness and numerical dominance of non-indigenous species.

\section{Species succession}

The maximum densities of amphipods in the littoral zones of the Delta Rhine showed sudden changes over the period 1987-2003 (Fig. 12). The populations of the native omnivorous Gammarus pulex and North American omnivorous $G$. tigrinus collapsed due to severe emissions of pesticides during the Sandoz disaster in 1986 (Den Hartog et al. 1992). G. pulex recovered slightly in 1987 but was subsequently replaced by G. tigrinus. Since 1990 G. pulex has only occurred in low densities. The Ponto-Caspian C. curvispinum, a filter-feeder, arrived in 1987 and reached maximum densities in 1991. This species out-competed the native as well as non-indigenous species by building extensive networks of mud-tubes, forming mud layers of several centimetres thick on firm substrate smothering sessile fauna and preventing settlement of species which need bare substrate (Van den Brink et al. 1993; Van der Velde et al. 1994). In 1990 and 1994 the omnivorous E. ischnus and D. villosus arrived from the Ponto-Caspian area, respectively. From that time on the densities of G. tigrinus continuously decreased, whereas densities of $D$. villosus strongly increased. Since 2001, numbers of $C$. curvispinum have also declined, but even so it remained the most numerous macroinvertebrate species. Our data describing the maximum densities of amphipods clearly documented the displacement of the native G. pulex and the North American invader G. tigrinus by the Ponto-Caspian species and the co-existence of the recent PontoCaspian invaders C. curvispinum, E. ischnus and D. villosus in the main channel of the Rhine.

\section{Discussion}

Economic development and globalisation of trade have resulted in a strong expansion of sea cargo and inland shipping (Karatayev et al. 2007). The construction of canals has resulted in an extensive Eurasian network of inland waterways and a stepwise increase of large rivers connected to the river Rhine. This network of waterways and shipping activities removed physical barriers for dispersal of species between previously biogeographically isolated regions and opened six principal invasion corridors for dispersal of aquatic species to the river Rhine (Bij de Vaate et al. 2002; Arbačiauskas et al. 2008; Karatayev et al. 2008; Panov et al. 2009).
Fig. 12 Temporal changes in maximum density of gammaridean species in the littoral zones of the river Rhine distributaries in the Netherlands

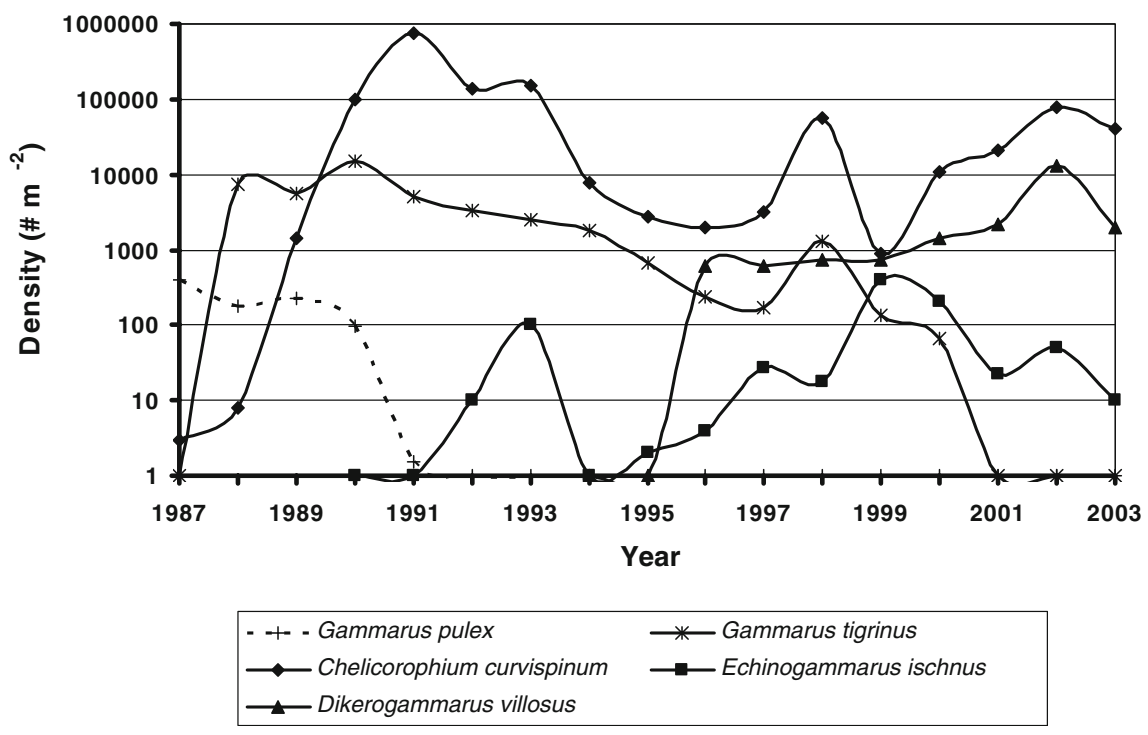


The stepwise development of a Eurasian network of inland waterways and the removal of some critical barriers in potential invasion corridors coincided with the punctuated increase of non-indigenous macroinvertebrate species richness in the river Rhine. The significant correlation between non-indigenous species richness and total surface area of catchments connected to the river Rhine confirms this pattern. Logarithmic species-area plots normally align the data linearly (Rosenzweig 1995). Our study shows that this relation also holds true for the diversity of non-indigenous macroinvertebrate species in networks of formerly biogeographically isolated river catchments.

The relative importance of dispersal vectors for non-indigenous species differs remarkably for various time spans. Deliberate introductions and accidental releases decrease, whereas transport via ships (ballast water and fouling of ship hulls) and natural migration or drift via man made waterways increase. Until the opening of the Main-Danube canal in 1992, the sea shipping routes and central corridor were the dominant pathways for the spread of non-indigenous species in the river Rhine. Currently, the southern corridor is the most important dispersal route. The south-western and Mediterranean corridors only appear to be of minor importance for the dispersal of non-indigenous species to the river Rhine.

Data availability allowed estimation of long distance dispersal rates of six non-indigenous species in the river Rhine and some connected waterways. The mean dispersal rates of these species did not differ significantly due to the low numbers of records and the large variance between dispersal rates estimated for various river sections. Moreover, dispersal rates may be underestimated due to the time lag between dispersal, establishment of populations and the first recorded observation of each non-indigenous species. In spite of underestimation, the calculated dispersal rates of non-indigenous species in the Rhine are rather high in comparison with literature data for other rivers. This even holds true for upstream dispersal of the bivalves such as Corbicula fluminea (up to $276 \mathrm{~km} \mathrm{year}^{-1}$ ). Josens et al. (2005) reported upstream dispersal of the amphipod species $C$. curvispinum and D. villosus in the river Meuse at rates of 15 and $30-40 \mathrm{~km}_{\text {year }}{ }^{-1}$, respectively. High upstream dispersal rates of non-indigenous macroinvertebrates in the river Rhine may be related to human mediated transport as a result of intensive shipping activities. The exotic bivalve Limnoperna fortunei also spread rapidly (around $250 \mathrm{~km}$ year $^{-1}$ ) in South American river tributaries that have intensive year-round shipping, but the upstream colonization in river tributaries with very restricted river traffic has been almost an order of magnitude slower (Karatayev et al. 2007). However, empirical evidence of shipping mediated upstream dispersal of invasive species is still scarce.

The water quality of the river Rhine has been strongly improved over the last decades (Bij de Vaate et al. 2006). Conventional biological water quality indicators, such as the Biological Monitoring Working Party index (Armitage et al. 1983), suggest a moderate ecological status of the river (Arbačiauskas et al. 2008). However, this indicator system does not yet take into account the effects of invasive species on the structure and functioning of river systems. Our site specific biological contamination scores for macroinvertebrate communities in the littoral zones of the Delta Rhine clearly indicate a decrease of the ecological status from moderate to bad, due to the strong dominance of non-indigenous species in richness and abundance. Currently, the river Rhine is amongst the inland waterways with the highest richness and abundance of non-indigenous species (Arbačiauskas et al. 2008; Panov et al. 2009). Nevertheless, the total number of non-indigenous species and their contribution to species richness of macroinvertebrate communities vary between river sections and sampling sites (IKSR 2002).

At many sampling sites in the river Rhine a relatively small group of mass invaders dominate in abundance by more than $80 \%$ (Van den Brink et al. 1993; Van der Velde et al. 1994; Haas et al. 2002; Bernauer and Jansen 2006; Bij de Vaate et al. 2006; Van Riel et al. 2006a; Baur and Schmidlin 2007). The analysis of temporal changes in species composition and abundance of amphipods in the littoral zone of the Delta Rhine clearly shows a replacement of native species by non-indigenous ones and changes in the dominance from established non-indigenous species to recent invaders. Similar replacements of native and non-indigenous species by new mass invaders are also observed in the Middle and Upper Rhine (Haas et al. 2002; Bernauer and Jansen 2006), in other large rivers in Europe (Dick and Platvoet 2000; MacNeil et al. 2004; Jazdzewski et al. 2004; Grabowski et al. 
2007; Arbačiauskas et al. 2008) and in North America (Palmer and Ricciardi 2004; Haynes et al. 2005; Kestrup and Ricciardi 2009).

A variety of mutually non-exclusive hypotheses have been suggested to explain the success of invaders in the river Rhine (Van der Velde et al. 2002, 2006a, b; Baur and Schmidlin 2007): (1) specific biological traits to facilitate dispersal, colonisation and population establishment, (2) high competitive ability with native species and released from enemies, (3) habitat alterations and environmental disturbances preventing strong interspecific competition by native species, (4) availability of vacant niches, (5) ecosystem instability (invasional meltdown), and (6) groups of co-adapted invaders.

Biological trait analyses show that aquatic invaders in North America and Europe are not a random selection of species (Karatayev et al. 2009). Invaders are over-represented by molluscs and crustaceans (mainly collector-filterers) and tolerate at least moderate amounts of organic pollution. Compared to native macroinvertebrates, invasive species and genera tend to reproduce more frequently and to have a higher abundance (higher propagule pressure), significantly more reproduction strategies enabling colonization by a single individual that releases viable offspring, larger size and longer life (providing resistance against mortality), food and feeding habits that allow the exploitation of food resources in streams more effectively, and are more dominant in their communities (Grabowski et al. 2007; Statzner et al. 2007). These traits may favour the establishment and population growth of invaders in disturbed systems, such as the river Rhine.

Dominance of macroinvertebrate communities in the littoral zones of the river Rhine is also determined by the high competitive ability of invaders (Van den Brink et al. 1991, 1993; Van Riel et al. 2006b; Van Riel 2007; Van der Velde et al. 2009) and the lack of enemies (enemy release hypothesis; Van der Velde et al. 2006b). Experimental studies show that interference competition can explain the replacement of the native G. pulex and the North American invader $G$. tigrinus by the Ponto-Caspian D. villosus and the co-existence of the Ponto-Caspian invaders $C$. curvispinum, E. ischnus and D. villosus in the river Rhine (Van Riel et al. 2007, 2009). Differences in predator avoidance behaviour between invasive and native species may also lead to increased predation on native species (Pennuto and Keppler 2008). In addition, human disturbances may prevent strong interspecific competition by native species. Competitive stress between native and invasive species is strongly influenced by local environmental circumstances, such as type of substratum, water temperature, salinity, current velocity and habitat heterogeneity (MacNeil et al. 2001, 2003, 2004; Wijnhoven et al. 2003; Palmer and Ricciardi 2004; MacNeil and Platvoet 2005; Van der Velde et al. 2009; Kestrup and Ricciardi 2009; Van Riel et al. 2009). The ongoing rise in water temperature in the river Rhine due to thermal pollution and global warming will also affect the establishment success of non-indigenous species and interspecific competition (Leuven et al. 2007). Extremely low summer discharges are generally accompanied by an increase in the ionic content and temperature of the river water. Experimental studies indicate a wider tolerance range and thus a higher competitive ability of non-indigenous species to water temperature and salt content in comparison with native species (Wijnhoven et al. 2003).

Recently, it has been hypothesized that high invasiveness of the river Rhine may also be related to the presence of vacant niches. The native fauna diversity of the river is rather low in comparison with rivers in south-eastern biogeographic regions, and this particularly holds for gammarids (Devin and Beisel 2008; Uehlinger et al. 2009). The Alps formed a barrier that reduced the accessibility of southern refuges during Pleistocene glaciations. This enhanced species extinction and impeded or delayed re-colonization from these refuges after the last glacial period (Uehlinger et al. 2009). Moreover, vacant niches were also created by human interventions such as large scale hydraulic engineering and severe water pollution, including accidental spills of toxic substances (e.g., the Sandoz disaster in 1986). The rapid spread of Ponto-Caspian species in the river Rhine coincides with the opening of invasion corridors and the improvement of river water quality (Van der Velde et al. 2000, 2002; Bij de Vaate et al. 2002, 2006).

Finally, a mass invader such as $D$. villosus also appear to impact on freshwater ecosystems through its exceptional predatory capabilities and is expected to have serious direct and indirect effects on ecosystem stability, with its invasion causing a larger "invasional meltdown" (Dick et al. 2002; Van der Velde et al. 2006a, b; Van Riel et al. 2006b). These 
processes may be facilitated by colonization of groups of co-adapted invaders. Karatayev et al. (2009) conclude that the ongoing spread of nonindigenous species not only affects biodiversity but also strongly shifts communities toward greater tolerance of organic pollution and increases the numbers of suspension feeders, thereby enhancing benthic pelagic coupling in aquatic ecosystems with high densities of invaders.

Several European countries have plans to develop or to improve waterways in order to increase inland shipping and to accommodate larger vessels (Panov et al. 2009). The current invasion corridors and future developments of the Eurasian network of inland waterways may highly facilitate the active and passive dispersal of invasive species across Eurasian inland waters and coastal ecosystems. Appropriate risk assessment tools are required to address ecological and socio-economic risks posed by humanmediated introductions of non-indigenous species and to formulate sound preventive measures and management options (Arbačiauskas et al. 2008; Panov et al. 2009). Novel risk assessment tools should not only account for negative effects of invaders on biodiversity, but must also weigh their effects on ecosystem functioning. In addition to negative impacts attention should also be paid to the potential positive effects of invaders, such as the application of filter-feeders to fight eutrophication of lakes or their significance as staple food for endangered fish species or waterfowl (MacNeil et al. 1999; Nienhuis 2008).

\section{Conclusions}

The number of non-indigenous macroinvertebrate species in the river Rhine exhibits a strong increase over the period from 1800 to 2005 , from $<1$ to more than 13 species per decade. The rapid range extension of non-indigenous species is strongly facilitated by shipping activities and the interconnection of river basins by canals. The sea harbours in the Delta Rhine (Atlantic and Northern invasion routes) and the recent Rhine-Main-Danube waterway (southern invasion corridor) are regarded as the most important gateways for the dispersal of non-indigenous species. A few non-indigenous species strongly dominate the littoral macroinvertebrate communities and cause harmful effects on the biological integrity of the river Rhine (such as displacements of native species). Mass invaders in the river Rhine are the isopod J. istri, the amphipods C. curvispinum, D. villosus, E. ischnus and G. tigrinus, and the bivalves D. polymorpha and C. fluminea. Currently D. rostriformis bugensis is also regarded as a mass invader in the Delta Rhine(Personal observation). A variety of mutually non-exclusive hypotheses have been suggested to explain the success of invaders in the river Rhine. Appropriate risk assessment tools are required to balance both negative and positive ecological impacts and to derive scientifically sound and feasible management options of invasive species in the river Rhine.

Acknowledgments This paper was presented as keynote lecture at the 15 th international conference on aquatic invasive species organised September 23-27, 2007 in Nijmegen, the Netherlands. The authors thank Jon Matthews for critical comments on an earlier draft of this paper.

Open Access This article is distributed under the terms of the Creative Commons Attribution Noncommercial License which permits any noncommercial use, distribution, and reproduction in any medium, provided the original author(s) and source are credited.

\section{References}

Arbačiauskas K, Semenchenko V, Grabowski M et al (2008) Assessment of biocontamination of benthic macroinvertebrate communities in European inland waterways. Aquat Invasions 3:211-230

Armitage PD, Moss D, Wright JF et al (1983) The performance of a new biological water quality score system based on macroinvertebrates over a wide range of unpolluted running-water sites. Water Res 17:333-347

Baur B, Schmidlin S (2007) Effects of invasive non native species on the native biodiversity of the river Rhine. In: Nentwig W (ed) Biological invasions. Ecological studies, vol 193. Springer, Berlin, pp 257-273

Bernauer D, Jansen W (2006) Recent invasions of alien macroinvertebrates and loss of native species in the upper Rhine river, Germany. Aquat Invasions 1:55-71

Bernerth H, Stein S (2003) Crangonyx pseudogracilis und Corophium robustum (Amphipoda), zwei neue Einwanderer im hessischen Main sowie Erstnachweis für Deutschland von C. robustum. Lauterbornia 48:57-60

Bij de Vaate A (2003) Degradation and recovery of the freshwater fauna in the lower sections of the rivers Rhine and Meuse. PhD thesis, Wageningen University, Wageningen

Bij de Vaate A, Jazdzewski K, Ketelaars HAM et al (2002) Geographical patterns in range extension of Ponto-Caspian macroinvertebrate species in Europe. Can J Fish Aquat Sci 59:1159-1174 
Bij de Vaate A, Breukel R, Van der Velde G (2006) Long-term developments in ecological rehabilitation of the main distributaries in the Rhine delta: fish and macroinvertebrates. Hydrobiologia 565:229-242

Bij de Vaate A, Klink AG, Greijdanus-Klaas M et al (2007) Effects of habitat restoration on the macroinvertebrate fauna in a foreland along the river Waal, the main distributary in the Rhine delta. River Res Appl 23:171-183

Cioc M (2002) The Rhine: an eco-biography, 1815-2000. University of Washington Press, Seattle

Den Hartog C, Van der Velde G (1987) Invasions by plants and animals into coastal, brackish and freshwater of the Netherlands. Proc K Acad Wet c 90:31-37

Den Hartog C, Van den Brink FWB, Van der Velde G (1992) Why was the invasion of the river Rhine by Corophium curvispinum and Corbicula species so successful? J Nat Hist 26:1121-1129

Devin S, Beisel J-N (2008) Geographic patterns in freshwater gammarid invasions: an analysis at the pan-European scale. Aquat Sci 70:100-106

Dick JTA, Platvoet D (2000) Invading predatory crustacean Dikerogammarus villosus eliminates both native and exotic species. Proc R Soc Lond Ser B 267:977-983

Dick JTA, Platvoet D, Kelly DW (2002) Predatory impact of the freshwater invader Dikerogammarus villosus (Crustacea: Amphipoda). Can J Fish Aquat Sci 59:1078-1084

Dillon RT, Wethington AR, Rhett JM et al (2002) Populations of the European freshwater pulmonate Physa acuta are not reproductively isolated from American Physa heterostropha or Physa integra. Invertebr Biol 121:226-234

European Community (2000) Directive 2000/60/EC of the European Parliament and of the Council of 23 October 2000 establishing a framework for community action in the field of water policy. Off J Eur Communities L327:172

Galil BS, Nehring S, Panov VE (2007) Waterways as invasion highways-impact of climate change and globalization. In: Nentwig W (ed) Biological invasions. Ecological studies, vol 193. Springer, Berlin, pp 59-74

Gergs R, Hanselmanna AJ, Eiselea I et al (2008) Autecology of Limnomysis benedeni Czerniavsky, 1882 (Crustacea: Mysida) in Lake Constance, southwestern Germany. Limnologica 38:139-146

Gittenberger E, Janssen AW, Kuijper WJ et al (1998) De Nederlandse zoetwatermollusken. Recente en fossiele weekdieren uit zoet en brak water. Nationaal Natuurhistorisch Museum Naturalis, KNNV uitgeverij and Stichting EIS-Nederland. Nederlandse Fauna 2:1-288 (in Dutch with English summary)

Gollasch S, Nehring S (2006) National checklist for aquatic alien species in Germany. Aquat Invasions 1:245-269

Grabowski M, Bacela K, Konopacka A (2007) How to be an invasive gammarid (Amphipoda: Gammaroidea)—comparison of life history traits. Hydrobiologia 590:75-84

Haas G, Bruncke M, Streit B (2002) Fast turnover in dominance of exotic species in the Rhine river determines biodiversity and ecosystem function: an affair between amphipods and mussels. In: Leppäkoski E, Gollasch S, Olenin S (eds) Invasive aquatic species of Europe. Distribution, impacts and management. Monographiae Biologicae. Kluwer, Dordrecht, pp 426-432
Haynes JM, Tisch NA, Mayer CM et al (2005) Benthic macroinvertebrate communities in southwestern Lake Ontario following invasion of Dreissena and Echinogammarus: 1983 to 2000. J N Am Benthol Soc 24:148-167

IKSR (2002) Das Makrozoobenthos des Rheins 2000. IKSRBericht 128-d. Internationale Kommission zum Schutze des Rheins, Koblenz (in German)

Jazdzewski K, Konopacka A, Grabowski M (2004) Recent drastic changes in the gammarid fauna (Crustacea, Amphipoda) of the Vistula River deltaic system in Poland caused by alien invaders. Divers Distrib 10:81-87

Josens G, Bij de Vaate A, Usseglio-Polatera P et al (2005) Native and exotic Amphipoda and other Peracarida in the River Meuse: new assemblages emerge from a fast changing fauna. Hydrobiologia 542:203-220

Karatayev AY, Padilla DK, Minchin D et al (2007) Changes in global economies and trade: the potential spread of exotic freshwater bivalves. Biol Invasions 9:161-180

Karatayev AY, Mastitsky SE, Burlakova LE et al (2008) Past, current, and future of the central European corridor for aquatic invasions in Belarus. Biol Invasions 10:215-232

Karatayev AY, Burlakova LE, Padilla DK et al (2009) Invaders are not a random selection of species. Biol Invasions. doi: 10.1007/s10530-009-9498-0

Kelleher B, Bergers PJM, Van den Brink FWB et al (1998) Effects of exotic amphipod invasions on fish diet in the Lower Rhine. Arch Hydrobiol 143:363-382

Kestrup ÅM, Ricciardi A (2009) Environmental heterogeneity limits the local dominance of an invasive freshwater crustacean. Biol Invasions

Ketelaars HAM, Gille L (1994) Range extension of the predatory cladoceran Bythotrephes longimanus Leydig 1860 (Crustacea, Onychopoda) in western Europe. Neth J Aquat Ecol 28:175-180

Klink A, Bij de Vaate A (1996) Hypania invalida (Grube 1860) (Polychaeta: Ampharetidae) in the Lower Rhine-new to the Dutch fauna. Lauterbornia 25:57-60

Leuven RSEW, Poudevigne I (2002) Riverine landscape dynamics and ecological risk assessment. Freshw Biol 47:845-865

Leuven RSEW, Ragas AMJ, Smits AJM et al (eds) (2006) Living rivers: trends and challenges in science and management. Hydrobiologia 565:1-371

Leuven RSEW, Slooter NAH, Snijders J et al (2007) The influence of global warming and thermal pollution on the occurrence of native and exotic fish species in the river Rhine. In: Van Os AG et al (eds) NCR days 2007: a sustainable river system. Netherlands Centre for River Research, Delft, pp 62-63

MacNeil C, Platvoet D (2005) The predatory impact of the freshwater invader Dikerogammarus villosus on native Gammarus pulex (Crustacea: Amphipoda); influences of differential microdistribution and food resources. J Zool 267:31-38

MacNeil C, Dick JTA, Elwood RW (1999) The dynamics of predation on Gammarus spp. (Crustacea: Amphipoda). Biol Rev 74:375-395

MacNeil C, Montgomery WI, Dick JTA et al (2001) Factors influencing the distribution of native and introduced Gammarus spp. in Irish river systems. Arch Hydrobiol 151:353-368 
MacNeil C, Bigsby E, Dick JTA et al (2003) Differential physico-chemical tolerances and intraguild predation among native and invasive amphipods (Crustacea); a field study. Arch Hydrobiol 156:165-179

MacNeil C, Prenter J, Briffa M et al (2004) The replacement of a native freshwater amphipod by an invader: roles for environmental degradation and intraguild predation. Can J Fish Aquat Sci 61:1627-1635

Maritime and Coastguard Agency (2006) Ballast water scoping study North Western Europe. Maritime and Coastguard Agency, Southampton

Molloy DP, Bij de Vaate A, Wilke T et al (2007) Discovery of Dreissena rostriformis bugensis (Andrusov 1897) in western Europe. Biol Invasions 9:871-874

Nienhuis PH (2008) Environmental history of the Rhine-Meuse delta. An ecological story on evolving human-environmental relations coping with climate change and sea-level rise. Springer, Dordrecht

Nienhuis PH, Buise AD, Leuven RSEW et al (2002) Ecological rehabilitation of the lowland basin of the Rhine (NW Europe). Hydrobiologia 478:53-72

Palmer ME, Ricciardi A (2004) Physical factors affecting the relative abundance of native and invasive amphipods in the St. Lawrence River. Can J Zool 82:1886-1893

Panov VE, Alexandrov B, Arbaciauskas K et al (2009) Assessing the risks of aquatic species invasions via European inland waterways: the concepts and environmental indicators. Integr Environ Assess Manag 5:110126

Pennuto C, Keppler D (2008) Short-term predator avoidance behavior by invasive and native amphipods in the Great Lakes. Aquat Ecol 42:629-641

Rajagopal S, Van der Velde G, Bij de Vaate A (2000) Reproductive biology of the Asiatic clams, Corbicula fluminalis and Corbicula fluminea in the river Rhine. Arch Hydrobiol 149:403-420

Ricciardi A, MacIsaac HJ (2000) Recent mass invasion of the North American Great Lakes by Ponto-Caspian species. Trends Ecol Evol 15:62-65

Rosenzweig ML (1995) Species diversity in space and time. Cambridge University Press, Cambridge

Smit H (1995) Macrozoobenthos in the enclosed Rhine-Meuse Delta. PhD thesis, Radboud University, Nijmegen

Statzner B, Bonada N, Dolédec S (2007) Biological attributes discriminating invasive from native European stream macroinvertebrates. Biol Invasions 10:517-530

Uehlinger U, Wantzen KM, Leuven RSEW et al (2009) River Rhine basin. In: Tockner K, Uehlinger U, Robinson C (eds) The rivers of Europe. Academic Press, Elsevier, London

Van den Brink FWB, Van der Velde G (1986) Observations on the seasonal and yearly occurrence and the distribution of Atyaephyra desmaresti (Millet, 1831) (Crustacea, Decapoda, Natantia) in the Netherlands. Hydrobiol Bull 19:193-198

Van den Brink FWB, Van der Velde G, Geelen JFM (1988) Life history parameters and temperature-related activity of an American crayfish, Orconectes limosus (Rafinesque, 1817) (Crustacea, Decapoda), in the area of the major rivers in The Netherlands. Arch Hydrobiol 114:275-289
Van den Brink FWB, Van der Velde G, Cazemier WG (1990) The faunistic composition of the freshwater section of the river Rhine in the Netherlands: present state and changes since 1900. In: Kinzelbach R, Friedrich G (eds) Die Biologie des Rheins. Limnologie aktuell, vol 1, pp 191-216

Van den Brink FWB, Van der Velde G, Bij de Vaate A (1991) Amphipod invasion on the Rhine. Nature 352:576

Van den Brink FWB, Van der Velde G, Bij de Vaate A (1993) Ecological aspects, explosive range extension and impact of a mass invader, Corophium curvispinum Sars, 1895 (Crustacea: Amphipoda), in the Lower Rhine (the Netherlands). Oecologia 93:224-232

Van der Velde G, Bij de Vaate A (2008) Invasions by alien macroinvertebrates and ecological rehabilitation: lessons from the Rhine. In: Bergmans W, De Iongh H, Simons H (eds) Forgotton kingdoms. Proceedings of a seminar on the conservation of small hidden species. IUCN, Amsterdam, pp 67-78

Van der Velde G, Platvoet D (2007) Quagga mussels Dreissena rostriformis bugensis (Andrusov, 1897) in the Main River (Germany). Aquat Invasions 2:261-264

Van der Velde G, Van den Brink FWB (1994) Does the Rhine still have characteristics of a river ecosystem? The longitudinal distribution of macroinvertebrates. Water Sci Technol 29:1-8

Van der Velde G, Paffen BGP, Van den Brink FWB et al (1994) Decline of Zebra mussel populations in the Rhine: competition between two mass invaders (Dreissena polymorpha and Corophium curvispinum). Naturwissenschaften 81:32-34

Van der Velde G, Rajagopal S, Kelleher B et al (2000) Ecological impact of crustacean invaders: general considerations and examples from the Rhine river. Crustac Issues 12:3-33

Van der Velde G, Nagelkerken I, Rajagopal S (2002) Invasions by alien species in inland freshwater bodies in Western Europe: the Rhine delta. In: Leppäkoski E, Gollasch S, Olenin $\mathrm{S}$ et al (eds) Invasive aquatic species of Europe. Distribution, impacts and management. Kluwer, Dordrecht, pp 360-372

Van der Velde G, Leuven RSEW, Ragas AMJ et al (2006a) Living rivers: trends and challenges in science and management. Hydrobiologia 565:359-367

Van der Velde G, Rajagopal S, Kuyper-Kollenaar M et al (2006b) Biological invasions: concepts to understand and predict global threat. In: Bobbink R, Beltman B, Verhoeven JTA et al (eds) Wetlands: functioning, biodiversity conservation, and restoration. Ecological studies, vol 191. Springer, Berlin, pp 61-90

Van der Velde G, Leuven RSEW, Platvoet D et al (2009) Environmental and morphological factors influencing predatory behaviour in an invasive gammaridean species (Dikerogammarus villosus). Biol Invasions. doi:10.1007/ s10530-009-9500-x

Van Riel MC (2007) Interactions between crustacean mass invaders in the Rhine food web. $\mathrm{PhD}$ thesis, Radboud University, Nijmegen

Van Riel MC, Van der Velde G, Bij de Vaate A (2006a) To conquer and persist: colonization and population development of the Ponto-Caspian amphipods Dikerogammarus villosus and Chelicorophium curvispinum on bare 
stone substrate in the main channel of the river Rhine. Arch Hydrobiol 166:23-39

Van Riel MC, Van der Velde G, Rajagopal S, Marguiller S, Dehairs F, Bij de Vaate A (2006b) Trophic relationships in the Rhine food web during invasion and after establishment of the Ponto-Caspian invader Dikerogammarus villosus. Hydrobiologia 56:39-58

Van Riel MC, Healy EP, Van der Velde G et al (2007) Interference competition among native and invader amphipods. Acta Oecologica 31:282-289
Van Riel MC, Van der Velde G, Bij de Vaate A (2009) Interference competition between alien invasive gammaridean species. Biol Invasions. doi:10.1007/s10530009-9486-4

Wijnhoven S, Van Riel MC, Van der Velde G (2003) Exotic and indigenous freshwater gammarid species: physiological tolerance to water temperature in relation to ionic content of the water. Aquat Ecol 37:151-158 